\title{
Pemberdayaan Ekonomi Berbasis Syariah Pada Muallaf Dayak Meratus di Dusun Papagaran
}

\author{
Rozzana erziaty ${ }^{1}$, Agus Purnomo² ${ }^{2}$ Umi Hani ${ }^{3}$ dan Abdul Wahab ${ }^{4}$ \\ 1,2,3,4Fakultas Studi Islam, Universitas Islam Kalimantan Muhammad Asyad Al-Banjary \\ e-mail : erziatyrozzana@gmail.com ${ }^{1}$, guspur80@gmail.com², umihani.uniska@gmail.com ${ }^{3}$, \\ 11abd.wahab@gmail.com ${ }^{4}$
}

\begin{abstract}
Papagaran is located in Patikalain Village Hantakan Sub-District Hulu Sungai Tengah Regency, which is located in the mountains of Meratus, the majority religion at animism. People who are new to Islam are called Muallaf, that ara still need help in adapting to their new conditions, whether material, knowledge, or social assistance that will protect and strengthen their hearts to embrace Islam. The purpose of the Community Empowerment Program (PPM) is to strengthen understanding of Islam in the economic field by regional potential, which is to assist in the management of production, marketing, and financing of agricultural products based on sharia. The method used by Rural Apracial Participatory. The population is the perpetrators of Dayak Meratus farming of 27 people. The activity was carried out in December 2019. The cognitive assessment results of the PPM pretest participants were $96.3 \%$ less $3.7 \%$ and $0 \%$ good category. The posttest was less than $0 \%$, the category was $55.6 \%$ and the good category was $44.4 \%$. The result of the t-test was accepted Hi, namely an increase in the knowledge and skills of participants in the community empowerment training.
\end{abstract}

Keywords: Muallaf, Dayak Meratus, Sharia-based economic empowerment

\begin{abstract}
Abstrak
Papagaran berada di desa Patikalain Kecamatan Hantakan Kabupaten Hulu Sungai Tengah yang berlokasi pegunungan meratus, mayoritas masyarakatnya pemeluk agama nenek moyang. Orang-orang yang baru masuk Islam disebut muallaf yaitu orang yang masih memerlukan bantuan dalam beradaptasi dengan kondisi baru mereka, baik bantuan materi maupun moril, pengetahuan ataupun sosial yang akan melindungi dan memantapkan hati untuk memeluk Islam. Tujuan Program Pemberdayaan Masyarakat (PPM) untuk penguatan dalam memahami Islam di bidang ekonomi sesuai dengan potensi wilayah yaitu meliupti asistensi manajemen Produksi, pemasaran dan keuangan hasil-hasil pertanian yang berbasis syariah. Metode yang digunakan Partisipatori Rural Apracial dengan pelaku usahatani muallaf dayak meratus berjumlah 27 orang. Kegiatan dilaksanakan bulan Desember 2019. Hasil penilaian kognitif peserta PPM pretest kategori cukup 96,3\% kurang 3,7\% dan kategori baik 0\%. Posttest berkategori kurang 0\%, kategori cukup 55,6\% dan kategori baik 44,4\% Hasi uji t di terima Hi yaitu terjadi peningkatan pengetahuan dan keterampilan peserta pelatihan pemberdayaan masyarakat.
\end{abstract}

Kata Kunci : Muallaf, Dusun Papagaran, Pemberdayaan ekonomi berbasis syariah

\section{PENDAHULUAN}

Sebagai bangsa yang religius, kita perlu berpikir serius tentang tanggung jawab moral-sosial terkait apa yang dihadapi bangsa ini. Agama dengan iman dan kepercayaannya diharapkan ada pada garda terdepan perubahan sosial dan perbaikan derajat hidup dan kehidupan umatnya (Melis, 2019).

Kata muallaf menunjuk pada orang yang ke-Islam-annya tidak sejak lahir. Artinya seseorang dikatakan muallaf jika awalnya dia beragama tertentu kemudian memutuskan untuk masuk Islam. orang yang baru masuk Islam kurang dari satu tahun, masih memerlukan bantuan dalam beradaptasi dengan kondisi baru mereka, baik itu berupa nafkah, memberikan pengetahuan tentang lingkup Islam, atau dengan kegiatan sosial yang akan melindungi dan memantapkan hati muallaf dalam memeluk Islam serta yang akan menciptakan lingkungan yang serasi dengan kehidupan baru mereka, baik moril maupun material. 
Dalam konsep pemikiran Islam yang tertuang dalam Alquran, muallaf dapat menerima Zakat Pada Surah At-Taubah Ayat 60 disebutkan bahwa para muallaf termasuk orang-orang yang berhak menerima zakat, ini memberikan implikasi dalam pemanfaatan zakat untuk muallaf sebagai modal pengembangan ekonomi keluarganya.

Etnis Dayak yang melakukan konversi keyakinan ke Islam menghadapi sejumlah masalah setelah mengambil keputusan untuk masuk Islam. Ada masalah yang berasal dari keluarga dan masyarakat maupun dari kalangan umat Islam sendiri yang tidak secara serius melakukan pembinaan. Selain itu masalah ekonomi juga dapat memberikan pengaruh tambahan pada perubahan keyakinan seseorang (Hidayati, 2014).

Berkaitan dengan hal tersebut, diperlukan peningkatan kapasitas terhadap masyarakat muallaf Dayak Meratus meliputi peningkatan kapasitas tentang pengembangan ekonomi berbasis syariah, sehingga diperlukan pemberdayaan masyarakat muallaf meliputi pemahaman konsep ekonomi syariah dan prakteknya sehari hari di masyarakat. Peningkatan kapasitas masyarakat dikenal dengan istilah pemberdayaan menurut (Widjajanti, 2011) dan yaitu suatu konsep pemebangunan melalui peran bersama masyarakat dalam program pembangunan adalah masyarakat berdaya atau memiliki daya, kekuatan atau kemampuan. Kemampuan berdaya mempunyai arti yang sama dengan kemandirian aspek fisik dan material, ekonomi, kelembagaan, kerjasama, kekuatan intelektual dan komitmen. Hal senada menurut (Erziaty, 2015) pemberdayaan menunjuk pada kemampuan orang, khususnya kelompok rentan dan lemah sehingga mereka memiliki kekuatan atau kemampuan dalam (a) memenuhi kebutuhan dasarnya dan (b) kemampuan menjangkau sumber-sumber produktif yang memungkinkan mereka dapat meningkatkan pendapatannya.

Dusun Papagaran secar administratif berada pada desa Patikalain Kecamatan Hantakan Kabupaten Hulu Sungai Tengah Provinsi Kalimantan Selatan yang lokasinya merupakan daerah lembah di pegunungan Meratus yang mayoritas masyarakatnya adalah pemeluk agama nenek moyang (animisme), seiring berjalannya waktu Penyebaran agama Islam yang dilakukan oleh Dakwah Mualaf Center Indonesia (MCI) mapun dari Tablik Muhammadiyah, kondisi ini memberikan pemikiran tim Program Pemberdayaan Masyarakat (PPM) program studi Ekonomi Syariah Fakultas Studi Islam Univesitas Islam Kalimantan untuk membantu komunitas muallaf etnis Dayak Meratus di Dusun Papagaran untuk memberikan penigkatan kapasitas pada bidang ekonomi berbasis syariah sesuai dengan potensi wilayah meliputi asistensi manajemen produksi, pemasaran dan keuangan hasil-hasil pertanian yang berbasis syariah.

\section{METODE}

\subsection{Metode Pelaksanaan Kegiatan}

Metode yang digunakan dalam PPM ini adalah Partisipatori Rural Apracial (PRA) yaitu suatu metode pendekatan dalam proses pemberdayaan dan peningkatan partisipasi masyarakat, yang tekanannya pada keterlibatan masyarakat berdasarkan pada kedekatan identitas, minat, perasaan memiliki, dan, tempat tinggal lokasi/kelompok (Mustanir \& Lubis, 2017). Penggunaan PRA untuk memfasilitasi pertukaran informasi, analisis dan tindakan antara para pemangku kepentingan. Penggunaan Metode PRA menerapkan pola partisiptif yang memlibatkan secara aktif masyarakat dalam pelaksanaan kegiatan pengabdian kepada masyarakat pada saat perencanaan pelaksanaan dan pengambilam keputusan serta melakukannya penilaian, analisis, hasil kegiatan oleh mereka sendiri (Muslim, 2007). 
Pelaksanaan program pemberdayan masyarakat dilaksanakan mengadopsi teknik (Amrina Rosyada, 2020) edukasi, latihan dan pendampingan yang dirangkum dalam dalam dua teknik pendampingan yaitu teori dan praktek.

a. Pendampingan teori

Tim pengabdian masyarakat akan memberikan gambaran teori mengenai Pemberdayaan ekonomi berbasis syariah. Penyampaian teori ini dilakukan secara klasikal untuk diberikan penjelasan secara teori tentang manajemen produksi, manajemen pemasaran dan manajemen keuangan hasil-hasil pertanian yang berbasis syariah. Penyampaian materi cara presentasi, diskusi dan tanya jawab.

b. Pendampingan praktek

Tim pengabdian pada masyarakat akan memberikan secara langsung (transfer soft skill) melalui pelatihan manajerial ekonomi syaraiah

\subsection{Program Kerja}

Program kerja PPM dilaksanakan secara terukur dengan langkah startegis secara koprehensip yang mengadopsi langkah kerja (Pratama et al., 2020) dan disesuaikan dengan kondisi pengabdian, sebagai berikut.

a. Facus Group Discussion (FGD) manajemen produksi dan distribusi hasil pertanian berbasis syariah.

b. Facus Group Discussion (FGD) Manajemen pemasaran pertanian berbasis Syariah

c. Facus Group Discussion (FGD) manajemen keuangan berbasis syariah

d. Evaluasi Kegiatan :

1. Penilaian perubahan pengetahuan (kognitif) dan keterampilan dari mitra dengan melakukan Pre test dan Post test, menurut (Siswati, 2018) diawali dengan pre test, semua peserta yang hadir yaitu sebanyak 27 orang ikut berpartisipasi dalam mengerjakan pre test yang dibagikan kepada masing- masing peserta. Kemudian diakhir kegiatan dilakukan post test untuk menilai perubahan pengetahuan setelah diberikan materi pendampingan.

2. Penilaian Kinerja Pengabdian Pada masyarakat sebagai umpat balik kepada tim P2M sebagai evaluasi pelaksanaan PPM yang telah dilakukan untuk perbaikan pelaksanaan PPM di masa akan datang.

\subsection{Khalayak Sasaran}

Khalayak sasaran strategis adalah komunitas muallaf etnis dayak meratus di Papagaran Desa Patikalain sebanyak 27 orang yang nantinya diharapkan dapat menularkan pengetahuan dan keterampilannya kepada muallaf lainnya.

\section{HASIL DAN PEMBAHASAN}

\subsection{Kegiatan Lapangan}

Pelaksanaan kegiatan dilakukan dalam bentuk FGD dengan pola ceramah, diskusi dan sistensi terhadap materi yang diberikan yang selanjutnya dilakukan simulasi kegiatan tentang : a). Manajemen Produksi berbasis syariah, b). Distribusi hasil pertanian berbasis syariah dan c). Manajemen keuangan berbasis syariah. Adapun Dokumentasi kegiatan PPM dapat dilihat pada Gambar 1. 

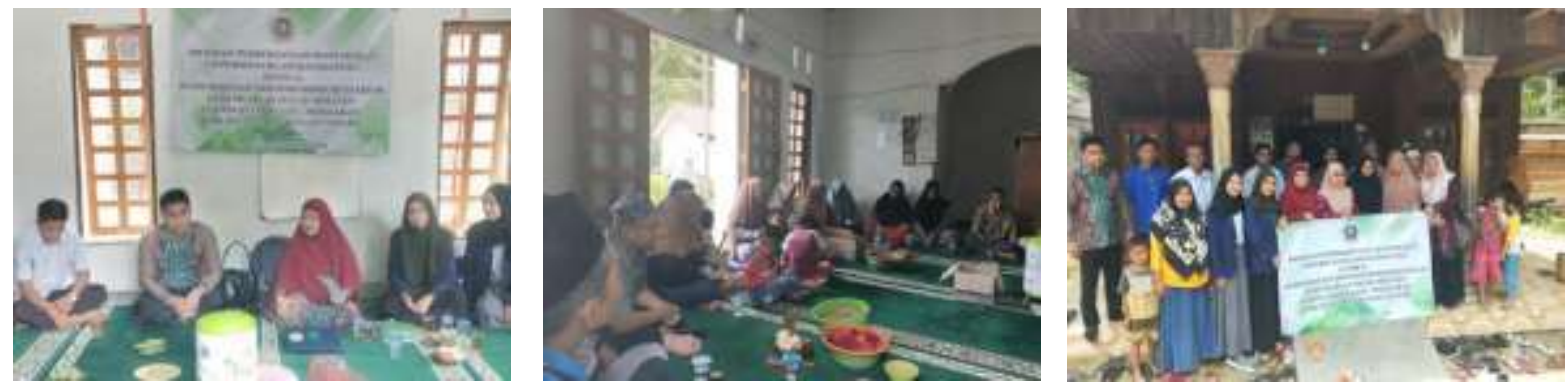

Gambar 1. Kegiatan Pemberdayaan Ekonomi Berbasis Syariah pada Muallaf Dayak Meratus

\subsection{Karakteristik Peserta PPM}

a. Jenis Kelamin Peserta PPM

Karaktersistik peserta PPM bervariasi dengan distribusi kelompok umur disajikan dalam bentuk tabel berikut ini

Tabel 1. Jenis Kelamin Peserta PPM

\begin{tabular}{ccc}
\hline Kelompok Umur (Tahun) & Frekuensi (orang) & Persentase (\%) \\
\hline$<29$ & 2 & 7.4 \\
$30-39$ & 11 & 40.7 \\
$40-49$ & 9 & 33.3 \\
$>50$ & 5 & 18.5 \\
Total & 27 & 100.0 \\
\hline
\end{tabular}

Sumber : data Kegiatan 2020

Tabel 1, memberikan gambaran sebaran umur peserta terbanyak pada kelompok umur 30 39 tahun $(40,7 \%)$ dan terendah pada kelompok umur $<29$ tahun $(7,4 \%)$. Dengan peserta termuda berumur 28 tahun dan tertua berumur 58 tahun, dengan demikian umur peserta PPM berada kelompok umur kerja (produktif). Menurut (Miswar, 2019) kelompok penduduk umur 0-14 tahun merupakan kelompok penduduk yang belum produktif secara ekonomis, kelompok penduduk umur 15-64 tahun sebagai kelompok penduduk yang produktif, dan kelompok penduduk umur 64 tahun ke atas sebagai kelompok yang tidak lagi produktif.

b. Jenis Kelamin Peserta PPM berikut ini.

Karaktersistik peserta PPM berdasarkan jenis kelamin disajikan dalam bentuk Tabel 2

Tabel 2. Jenis Kelamin Peserta PPM

\begin{tabular}{lcc}
\hline \multirow{2}{*}{ Jenis Kelamin } & \multicolumn{2}{c}{ Jumlah Peserta PPM } \\
& Frekuensi (orang) & Persentase (\%) \\
\hline Pria & 14 & 51,85 \\
Wanita & 13 & 48,15 \\
Total & 27 & 100,00 \\
\hline
\end{tabular}

Sumber : data Kegiatan 2020.

Data tabel 2, memberikan gambaran sebaran peserta berdasarkan jenis kelamin Pria $(51,85 \%)$ sedikit lebih tinggi dibandingkan kelompok Waniata $(48,15 \%)$. Dengan kondisi demikian memberikan gambaran bahwa peserta PPM mualaf dayak meratus antusias mengikuti program 
pemberdayaan, dikarenakan hampir sama peserta pria 14 orang dan peserta wanita 13 orang. Sehigga memberikan keseetraraan gender dalam peningkatan SDM muallaf. Menurut (Elizabeth, 2016), pemberdayaan menjadi strategi penting dalam peningkatan peran dan peluang wanita yang tidak hanya berkegiatan dibidang domestik.

\section{c. Tingkat Pendidikan Peserta PPM}

Berdasarkan jumlah peserta pelatihan PPM sebanyak 27 orang dengan tingkat pendidikan bervariasi dari tingkat pendidikan SD sampai dengan SMA dengan sebaran tingkat pendidikan di sajikan dalam bentuk grafik sebagai berikut.

Tabel 3. Distribusi Peserta PPM Berdasarkan Tingkat Pendidikan

\begin{tabular}{lcc}
\hline \multirow{2}{*}{ Tingkat Pendidikan } & \multicolumn{2}{c}{ Jumlah Peserta PPM } \\
& Frekuensi (orang) & Persentase (\%) \\
\hline SD/Sederajat & 21 & 77,78 \\
SMP/Sederajat & 3 & 11,11 \\
SMA/Sederajat & 3 & 11,11 \\
Total & 27 & 100,00 \\
\hline
\end{tabular}

Sumber : data Kegiatan 2020

Berdasarkan data tabel 3. memberikan gambaran responden terbanyak pada kelompok pendidikan SD sebanyak 21 orang atau 77,7 \% dari jumlah peserta PPM, kemudian diikuti oleh kelompok SMP dan SMA masing sebanyak 3 orang $(11,11 \%)$.

\subsection{Evaluasi Kegiatan}

Penilaian hasil kegiatan, dilakukan antara lain dengan memberikan kuesioner tentang persepsi peserta terhadap pelaksanaan kegiatan yang berkaitan dengan kualitas pembicara, bahan materi, suasana dan prasarana kegiatan, Berikut ini adalah gambaran penilaian peserta yang telah dikategorisasikan terhadap kinerja kegiatan.

Tabel 4. Respon Peserta terhadap Kinerja Kegiatan PPM

\begin{tabular}{lcccccccc}
\hline \multirow{2}{*}{$\begin{array}{l}\text { Kategori } \\
\text { penilaian }\end{array}$} & \multicolumn{3}{c}{ Frequency (orang) } & \multicolumn{5}{c}{ Persentase (\%) } \\
& Pembicara & Materi & Suasana & Sarana & Pembicara & Materi & Suasana & Sarana \\
\hline Baik & 14 & 9 & 18 & 10 & 51.9 & 33.3 & 66.7 & 37.0 \\
Cukup & 12 & 17 & 8 & 17 & 44.4 & 63.0 & 29.6 & 63.0 \\
Kurang & 1 & 1 & 1 & 0 & 3.7 & 3.7 & 3.7 & 0 \\
Total & 27 & 27 & 27 & 27 & 100.0 & 100.0 & 100.0 & 100.0 \\
\hline
\end{tabular}

Sumber : data Kegiatan 2020.

Tabel 4, menjelaskan persepsi peserta terhadap kinerja kegiatan PPM dinilai baik oleh seluruh peserta baik dari segi pembicara, materi, suasana maupun sarana dan prasarana.

\subsection{Evaluasi Aspek Kognetif Peserta}


Evaluasi dilakukan diawal kegiatan (Pre test) sebelum proses penyampaian materi dan setelah penyampaian materi (Post test). Adapun hasil evaluasi kognitif peserta dapat dilihat pada tabel 5 .

Tabel 5. Nilai Evaluasi Pre test dan Post Test

\begin{tabular}{lcc|cc}
\hline Kriteria & \multicolumn{2}{c|}{ Pre Tes } & \multicolumn{2}{c}{ Post Tes } \\
& Frekuensi (orang) & Persentase (\%) & Frekuensi (orang) & Persentase (\%) \\
\hline Baik & 0 & 0 & 12 & 44,4 \\
Cukup & 26 & 96,3 & 15 & 55,6 \\
Kurang & 1 & 3,7 & 0 & 0 \\
Total & 27 & 100 & 27 & 100 \\
\hline
\end{tabular}

Sumber : data Kegiatan 2020.

Tabel 2, menjelaskan hasil pre test kognitif peserta terhadap materi yang diberikan tersebar pada kategori cukup 96,3\% dan kurang 3,7\%. Kemudian setelah di berikan materi dan pelatihan pemberdayaan ekonomi berbasis syariah pada muallaf Dayak Meratus terjadi peningkatan pemahaman peserta PPM dengan hasil post tets tidak ditemukan lagi peserta yang berpengatahuan kurang (0\%), dengan sebaran kategori pengetahuan berada pada kategori cukup sebesar 55,6\% dan kategori baik sebesar $44,4 \%$. Selanjutnya hasil uji t data berpasangan yang disajikan secara lengkap pada tabel 6.

Tabel 6. Hasil Uji t Data Berpasangan

\section{Paired Samples Test}

\begin{tabular}{|c|c|c|c|c|c|c|c|c|}
\hline \multicolumn{6}{|c|}{ Paired Differences } & \multirow[b]{3}{*}{$t$} & \multirow[b]{3}{*}{$d f$} & \multirow[b]{3}{*}{ Sig. (2-tailed } \\
\hline & \multirow[b]{2}{*}{ Mean } & \multirow[b]{2}{*}{ Std. Deviation } & \multirow{2}{*}{$\begin{array}{l}\text { Std. Error } \\
\text { Mean }\end{array}$} & \multicolumn{2}{|c|}{$\begin{array}{c}\text { 95\% Confidence Interval of the } \\
\text { Difference }\end{array}$} & & & \\
\hline & & & & Lower & Upper & & & \\
\hline Pair 1 PRE TEST-POST TEST & -37.037 & 12.030 & 2.315 & -41.796 & -32.278 & -15.997 & 26 & .000 \\
\hline
\end{tabular}

Sumber : data Kegiatan 2020.

Tabel 3, nilai sig 0,000 $<0,05$, maka terjadi perbedaan yang signifikan antara nilai kognitif peserfta PPM sebelum diberi pelatihan dan setelah diberi pelatihan pemberdayaan ekonomi berbasis syariah pada muallaf Dayak Meratus. Dengan demikian dapat dikatakan kegiatan PPM berhasil dengan baik meningkatkan pengetahuan dan keterampilan masyarakat muallaf Dayak Meratus dibidang ekonomi pertanian berbasis syariah.

\section{KESIMPULAN}

\subsection{Kesimpulan}

Kegiatan pemberdayaan ekonomi berbasis syariah pada muallaf Dayak Meratus di dusun Papagaran Desa Patikalain Kecamatan Hantakan Kabupaten Hulu Sungai Tengah dapat disimpulkakan :

1. Kegiatan PPM berjalan lancar sesuai dengan rencana yang telah disusun 
2. Terhadap pencapaian materi khalayak sasaran terjadi peningkatan pemahaman (Kognitif) di akhir kategori kurang 0\%, kategori cukup 55,6\% dan kategori baik 44,4\% yang sebelumnya kategori cukup 96,3\% dan kurang 3,7\% dan kategori baik $0 \%$.

\subsection{Saran}

Berdasarkan pelaksanan dan evaluasi hasil kegiatan maka disarankan untuk anggota kelompok muallaf untuk menerapkan semua pengetahuan dan mempraktekannya dalam kegiatan ekonomi khususnya dibidang pertanian sesuai dengan potensi wilayah yang ada.

\section{UCAPAN TERIMAKASIH}

Ucapan terima kasih kepada Pusat Pengabdian Kepada Masyarakat Universitas Islam Kalimantan Muhammad Arsyad Albanjari yang telah memberikan dukungan melalui Dana APBU Uniska TA 2019/2020 Nomor Kontrak : 414/UNISKA-P2M/XI/2019.

\section{DAFTAR PUSTAKA}

Amrina Rosyada. (2020). Pendampingan Pembentukan Badan Usaha Milik Desa (Bumdes) Desa Kendalasem Wedung Demak. Dinamisia : Jurnal Pengabdian Kepada Masyarakat, 3(2), 235-243. https://doi.org/10.31849/dinamisia.v3i2.3292

Elizabeth, R. (2016). Pemberdayaan Wanita Mendukung Strategi Gender Mainstreaming dalam Kebijakan Pembangunan Pertanian di Perdesaan. Forum Penelitian Agro Ekonomi, 25(2), 126. https://doi.org/10.21082/fae.v25n2.2007.126-135

Erziaty, R. (2015). Pemberdayaan Ekonomi Potensial Masjid Sebagai Model Pengentasan Kemiskinan. Al Iqtishadiyah ; Jurnal Ekonomi Syariah Dan Hukum Ekonomi Syariah, 2(2), 82-98. https://ojs.uniska-bjm.ac.id/index.php/IQT/article/view/377/336

Hidayati, S. (2014). Problematika Pembinaan Muallaf Di Kota Singkawang Dan Solusinya. XV(1), 111136. http://ejournal.uin-suka.ac.id/dakwah/jurnaldakwah/article/view/300

Melis, M. (2019). Relevansi Agama dan Kemiskinan; Upaya Memahami Kemiskinan Secara Multidimensional dan Solusi yang Ditawarkan dalam Ekonomi Islam. SALAM: Jurnal Sosial Dan Budaya Syar-I, 6(2), 179-190. https://doi.org/10.15408/sjsbs.v6i2.11227

Miswar, T. R. (2019). Pengaruh Faktor-faktor Demografi Terhadap Pertumbuhan Ekonomi di Kota Langsa. Jurnal Samudra Ekonomika, 3(1), 164-176. https://doi.org/https://doi.org/10.0123/jse.v3i2.1890

Muslim, A. (2007). Pendekatan Partisipatif Dalam Pemberdayaan Masyarakat. Aplikasi Ilmu-Ilmu Agama, VIII(2), 89-103. https://doi.org/10.1177/0734282911435461

Mustanir, A., \& Lubis, S. (2017). Participatory Rural Appraisal in Deliberations of Development Planning. 163(Icodag), 316-319. https://doi.org/10.2991/icodag-17.2017.60

Pratama, A. K. Y., Wisdaningrum, O., \& Nugrahani, M. P. (2020). Pendampingan dan Penerapan Teknologi Untuk Peningkatan Produktivitas Usaha Mikro Gula Semut. DINAMISIA: Jurnal Pengabdian Kepada Masyarakat, 4(2), 275-284.

Siswati, L. (2018). Pemberdayaan Ibu Rumah Tangga Melalui Pelatihan Membuat Hantaran Pernikahan Melayu Motif Satwa. Dinamisia : Jurnal Pengabdian Kepada Masyarakat, 2(2), 205210. https://doi.org/10.31849/dinamisia.v2i2.1223

Widjajanti, K. (2011). Jurnal Ekonomi Pembangunan Model pemberdayaan masyarakat. 12. https://publikasiilmiah.ums.ac.id/handle/11617/1306 